\title{
Interleukin-15 Receptor Subunit Alpha
}

National Cancer Institute

\section{Source}

National Cancer Institute. Interleukin-15 Receptor Subunit Alpha. NCI Thesaurus. Code C126970.

Interleukin-15 receptor subunit alpha (267 aa, $\sim 28 \mathrm{kDa}$ ) is encoded by the human IL15RA gene. This protein is involved in interleukin-dependent signaling. 